\title{
RANCANGAN UNDANG-UNDANG \\ PENGETAHUAN TRADISIONAL DAN EKSPRESI BUDAYA \\ TRADISIONAL DITINJAU DARI ASPEK BENEFITS PASAL 8J \\ UNCBD
}

\author{
Yeni Eta \\ Fakultas Hukum Universitas Brawijaya \\ J1. MT. Haryono 169 Malang \\ Email: yenni.eta@ub.ac.id
}

\begin{abstract}
Traditional Knowledge and Traditional Cultural Expressions in Indonesian positive law isset out in the legal system of intellectual property rights, in this case is the Law. 19 of 2002 on Copyright. However, the setting of Traditional Knowledge and Traditional Cultural Expressions in Law. 19 of 2002 is very difficult to implement, due tothe difference principle contained in the legal system of intellectual property rights which are individual whereas traditional knowledge and traditional cultural expressions are communal. Under these conditions, Indonesia should have rules of traditional knowledge and traditional regulated expression sui generis. Recently, these rules are still in the draft form of Law 's Traditional Knowledge Traditional Cultural Expressions. Therefore, researchers analyzed more deeply about legal protections onthe Bill of Traditional Knowledge and Traditional Cultural Expressions from the aspect of a fair distribution of benefits based on Article $8 J$ United Nations Convention on Biological Diversity. By using normative research, the researchersfound that the billof PTEBT is more assertive and clear in regard to thePTEBT, in this case to include the protection of PTEBT commercial interests, including the scope of protection of PTEBT utilization and sharing results. This isin accordance with the aspects of equitable sharing of benefits based on Article $8 \mathrm{~J}$ United Nations Convention on Biological Diversity.
\end{abstract}

Key words: traditional knowledge, traditional cultural expression, the draft law, the United Nations Convention on Biological Diversity

\begin{abstract}
Abstrak
Pengetahuan Tradisional dan Ekspresi Budaya Tradisional dalam hukum positif Indonesia diatur dalam sistem hukum Hak Kekayaan Intelektual, dalam hal ini adalah UU No. 19 Tahun 2002 tentang Hak Cipta. Namun demikian, pengaturan Pengetahuan Tradisional dan Ekspresi Budaya Tradisional dalam Undang-undang No. 19 Tahun 2002 sangat sulit untuk diterapkan karena perbedaan prinsip yang terdapat dalam sistem hukum Hak Kekayaan Intelektual yang bersifat individual dengan pengetahuan tradisional dan ekspresi budaya tradisional yang bersifat komunal. Berdasarkan hal tersebut maka Indonesia harus memiliki aturan pengetahuan tradisional dan ekspresi tradisional yang diatur secara sui generis. Pada perkembangannya aturan tersebut kini masih dalam bentuk Rancangan Undang-Undang Pengetahuan Tradisional an Ekspresi Budaya Tradisional. Oleh karena itu peneliti menganalisis lebih dalam tentang perlindungan hukum Rancangan Undang-undang Pengetahuan Tradisional dan Ekspresi Budaya Tradisional ditinjau dari aspek pembagian keuntungan yang adil (benefits) berdasarkan Pasal
\end{abstract}


8j United Nations Convention on Biological Diversity. Dengan menggunakan jenis penelitian yuridis normatif, maka ditemukan hasil penelitian bahwa RUU PTEBT lebih tegas dan jelas dalam mengatur PTEBT, dalam hal ini meliputi tujuan perlindungan PTEBT guna kepentingan komersial, termasuk di dalamnya adalah ruang lingkup perlindungan PTEBT dan Pembagian hasil pemanfaatan. Hal ini telah sesuai dengan aspek pembagian keuntungan yang adil (benefits) berdasarkan Pasal 8j United Nations Convention on Biological Diversity.

Kata kunci: pengetahuan tradisional, ekspresi budaya tradisional, Rancangan Undang-undang, United Nations Convention on Biological Diversity

\section{Latar Belakang}

Sistem Hukum Hak atas Kekayaan Intelektual (sebagai terjemahan harfiah dari Intellectual Property Rights) yang telah dibangun oleh negara-negara maju dan menjadi perjanjian internasional melalui Agreement on Trade Related Aspects of Intellectual Property Rights (untuk penulisan selanjutnya disingkat TRIPs Agreement) telah menimbulkan pertentangan antara negara maju (developed country) dengan negara berkembang (developing country).

Pertentangan yang terjadi tersebut merupakan konsekuensi adanya globalisasi ekonomidenganmotorliberalisasiperdagangan dan keuangan yang tidak selalu memberikan keuntungan bagi semua pihak. Globalisasi bukanlah suatu gerakan yang harus ditahan dan dibendung, tetapi sebaliknya memerlukan nalar logis untuk menjauhkannya dari efek buruk bagi keadilan.Opini tentang efek buruk bagi keadilan ini berkembang dari adanya pandangan kaum neoliberal yang berpendapat bahwa hanya pelaku swasta yang dapat menikmati Hak atas Kekayaan Intelektual (untuk penulisan selanjutnya disingkat HKI). Dengan demikian, kepemilikan HKI harus dimiliki secara individual, baik orang pribadi maupun perusahaan. Hal ini didasarkan pada alasan bahwa bila HKI mereka tidak dilindungi, maka kegiatan inovasi, investasi dan pengembangan teknologi akan terhambat karena tidak adanya kesempatan memperoleh keuntungan finansial yang lahir dari adanya hak tersebut. Pandangan di atas sepertinya menafikan kemungkinan keuntungan sosial dapat menjadi pendorong inovasi, bahkan pemerintah bisa saja memiliki HKI tertentu.

Terdapat banyak kasus dimana gagasan dan kreatifitas dikembangkan tanpa memikirkan keuntungan ekonomi semata. Dalam hal ini, perlu juga dipertimbangkan ide tentang perlunya HKI yang berorientasi pada kepemilikan publik atau komunal. Indonesia adalah salah satu negara yang telah mengakomodir tentang hak komunal dalam sistem HKI nasionalnya.Oleh karena itu, Indonesia sebagai negara yang sangat kaya dengan keanekaragaman etnik dan budaya yang berasal dari pengetahuan tradisional masyarakat lokal harus mampu memanfaatkan perlindungan yang diberikan dalam sistem Hukum HKI guna meningkatkan kesejahteraan dari masyarakat komunal. 
Dalam hal ini HKI juga mencakup konsep indikasi geografis, genetic resources, dan pengetahuan tradisional.Terkait dengan penelitian ini maka pengetahuan tradisional (sebagai terjemahan harfiah dari traditional knowledge) yang dilindungi dalam sistem Hukum HKI menjadi sangat penting untuk menggairahkan laju perekonomian dunia yang pada akhirnya membawa kesejahteraan pada umat manusia. Pengetahuan tradisional adalah istilah umum yang mencakup ekspresi kreatif, informasi dan know how yang secara khusus mempunyai ciri-ciri sendiri dan dapat mengidentifikasi unit sosial. ${ }^{1}$ Pengetahuan tradisional merujuk pada pengetahuan, inovasi, dan praktik dari masyarakat asli dan lokal di seluruh dunia.Dikembangkan dari pengalaman melalui negara-negara dan diadaptasi ke budaya lokal dan lingkungan, pengetahuan tradisional ditransmisikan secara lisan dari generasi ke generasi.Hal itu menjadi kepemilikan secara kolektif dan mengambil bentuk cerita, lagu, foklore, peribahasa, nilai-nilai budaya, keyakinan, ritual, hukum masyarakat, bahasa daerah dan praktek pertanian, mencakup pengembangan spesies tumbuhan dan keturunan binatang. Pengetahuan tradisional utamanya merupakan praktik alamiah, secara khusus seperti dalam wilayah pertanian, perikanan, kesehatan, hortikultural dan kehutanan. ${ }^{2}$
Sejalan dengan hal tersebut pengetahuan tradisional sangat dibutuhkan untuk dijadikan nilai tambah bagi setiap daerah di Indonesia, yaitu dengan memanfaatkan pengetahuan tradisional dari masyarakat tradisional/ asli yang meliputi: ${ }^{3}$

1. Obat-obatan tradisional yang proses pembuatannya didasarkan pada pengetahuan umum atau kebiasaan masyarakat setempat.

2. Karya-karya budaya: hasil tenun, songket, anyaman, dan kerajinan tangan.

3. Karya-karya seni: seni tari, seni ukir, dan seni suara.

Terkait dengan pengetahuan tradisional, Indonesia di manca negara telah dikenal memiliki beragam karya seni, mulai dari patung Bali, tenunan, batik, dan anyaman. Namun, sayangnya produk pengetahuan tradisional tersebut tidak sedikit telah dinyatakan sebagai milik asing, antara lain produk kerajinan rotan yang terdaftar di lembaga paten AS atas nama orang Amerika. ${ }^{4}$ Dengan merebaknya industrialisasi di seluruh dunia, terjadi benturan kepentingan antara pemilik pengetahuan tradisional dengan pengusaha yang sebagian besar penganut HKI. Negara-negara maju menuduh bahwa negara berkembang melakukan pembajakan HKI secara besar-besaran. Benturan kepentingan juga disebabkan bahwa di satu sisi masyarakat pemilik pengetahuan tradisional menganggap

1 Budi Agus Riswandi dan M. Syamsudin, Hak Kekayaan Intelektual dan Budaya Hukum, RajaGrafindo Persada, Jakarta, 2005, hlm. 26.

2 Article 8J Traditional Knowledge, Innovationss, and Practices Introduction.

3 Nina Nuraini, Wewenang Daerah Otonom dalam Meningkatkan Pembangaunan Daerah melalui Pemanfaatan HAKI Bidang Pengetahuan Tradisional dalam Jurnal Hukum, Manajemen dan Ekonomi, Volume 7 No. 3, Februari 2006.

4 Adrian Sutedi, Hak atas Kekayaan Intelektual, Sinar Grafika, Jakarta, 2009, hlm. 6. 
bahwa seharusnya dalam pemanfaatan pengetahuan tradisional dan sumber genetik, negara industri maju tidak mengabaikan kepentingan komunitas pemilik pengetahuan tradisional. Namun pada sisi yang lain negara industri maju menganggap sumber hayati dan pengetahuan tradisional sebagai warisan leluhur (common heritage of mankind) sehingga bebas dimanfaatkan oleh siapapun juga. ${ }^{5}$ Oleh karena itu terjadi ketidakcocokan pengaturan pengetahuan tradisional dalam sistem hukum HKI sehingga diperlukan suatu aturan hukum yang sui generis.

Berdasar hal tersebut arti penting perlindungan hukum terhadap pengetahuan tradisional bagi Indonesia memiliki nilai yang sangat strategis.Nilai strategis tersebut dapat dilihat dari segi budaya, ekonomi, dan sosial. Dari segi budaya, tampak sekali bahwa dengan adanya perlindungan terhadap pengetahuan tradisional maka pelestarian budaya bangsa akan tercapai. Saat ini bangsa Indonesia terkenal dengan keanekaragaman budayanya baik dari sisi seni, obat-obatan, dan lain sebagainya. Selanjutnya dari segi sosial, dengan perlindungan terhadap pengetahuan tradisional maka pelestarian nilai-nilai socialjuga akan terjaga dan terpelihara. Dalam hal ini nilai sosial adalah nilai yang dianut oleh suatu masyarakat, mengenai apa yang dianggap baik dan apa yang dianggap buruk oleh masyarakat. Sebagai contoh, orang menanggap menolong memiliki nilai baik, sedangkan mencuri bernilai buruk. Woods mendefinisikan nilai sosial sebagai petunjuk umum yang telah berlangsung lama, yang mengarahkan tingkah laku dan kepuasan dalam kehidupan sehari-hari.

Sedangkan nilai budaya merupakan nilai-nilai yang disepakati dan tertanam dalam suatu masyarakat, lingkup organisasi, lingkungan masyarakat, yang mengakar pada suatu kebiasaan, kepercayaan (believe), simbol-simbol, dengan karakteristik tertentu yang dapat dibedakan satu dan lainnya sebagai acuan prilaku dan tanggapan atas apa yang akan terjadi atau sedang terjadi. Oleh karena itu pemerintah tidak lagi bisa mengabaikan pengetahuan tradisional yang dimiliki oleh masyarakat Indonesia. Terakhir dari segi ekonomi, yaitu dengan dilakukannya perlindungan terhadap pengetahuan tradisional maka nilai ekonomi yang akan dihasilkan dari pengetahuan tradisional akan memiliki nilai tambah, artinya devisa negara dapat ditingkatkan. Hal ini menjadi logis mengingat selama ini eksploitasi terhadap pengetahuan tradisional hanya sebatas pemanfaatan secara konvensional, tetapi belum dikembangkan sehingga menjadi sesuatu yang sangat bernilai. $^{6}$

Jalan keluar yang paling elegan dalam mengoptimalkan perlindungan produk budaya dari pihak asing adalah dengan mengupayakan

5 Perlindungan Hak atas Kekayaan Intelektual terhadap Pengetahuan Tradisional, www.alsaindonesia. org, diakses 10 Maret 2012 pukul 10.00 WIB.

6 Budi Agus Riswandi dan M. Syamsudin, Op.cit., hlm. 39-40. 
perlindungan hukum secara sui generis, di luar sistem Hak Kekayaan Intelektual yang berlaku secara konvensional.Perlindungan Hak Kekayaan Intelektual yang bersifat individual memang tidak sepenuhnya bisa diterapkan dan digeneralisasi terhadap Hak Kekayaan Intelektual yang bersifat komunal. Pembagian keuntungan maupun pembagian manfaat terhadap HKI secara komunal, kecil kemungkinan diterapkan dalam perlindungan Hak Kekayaan Intelektual secara individual. Namun demikian, sangatlah penting untuk menganalisis lebih dalam apakah aturan hukum pengetahuan tradisional yang sui generis dalam rancangan Undang-undang Pengetahuan Tradisional dan Ekspresi Budaya Tradisional tersebut nantinya ketika berlaku dan diterapkan berkesuaian dengan Pasal 8j United Nations Convention on Biological Diversity sehingga nantinya ketika diberlakukan dan diterapkan diharapkan akan lebih baik dalam memberikan perlindungan hukum dan kemanfaatan ekonomi, sosial dan budaya bagi masyarakat tradisional pada khususnya dan bangsa Indonesia pada umumnya.

Berpijak pada latar belakang sebagaimana yang telah diuraikan maka rumusan permasalahan adalah sebagai berikut: bagaimana perlindungan hukum Rancangan Undang-undang Pengetahuan Tradisional dan Ekspresi Budaya Tradisional ditinjau dari aspek pembagiankeuntungan yang adil (benefits) berdasarkan Pasal 8j United Nations

\section{Convention on Biological Diversity?}

Penelitian ini menggunakan Jenis Penelitian hukum normatif yaitu penelitian hukum yang dilakukan dengan meneliti bahan pustaka atau disebut juga penelitian hukum studi kepustakaan. Penelitian ini menggunakan kajian yuridis normatif yaitu dengan mengkaji dan menganalisis bahan hukum, berupa bahan hukum primer dan sekunder yang terkait dengan pengetahuan tradisional.

Penelitian ini menggunakan pendekatan peraturan perundang-undangan (statute approach) yang dilakukan untuk meneliti peraturan perundang-undangan dan kebijakan yang menjadi landasan pengaturan pengetahuan tradisional. Statute approach adalah pendekatan yang menggunakan peraturan perundang-undangan, karena yang diteliti adalah berbagai aturan hukum yang menjadi fokus penelitian. Penelitian normatif dapat dan harus memanfaatkan hasil penelitian empiris, namun ilmu empiris itu berstatus sebagai ilmu bantu, sehingga tidak merubah hakikat ilmu hukum sebagai ilmu normatif. ${ }^{7}$

1. Bahan Hukum

Dalam penelitian hukum normatifterdiri atas bahan hukum primer dan sekunder, yaitu:

a. Bahan Hukum Primer, yaitu bahan hukum yang terdiri dari peraturan perundang-undangan yang terkait langsung maupun tidak langsung dengan pengetahuan tradisional.

b. Bahan Hukum Sekunder, yaitu bahan-

7 Jonny Ibrahim, Teori dan Metodologi Penelitian Normatif, Bayumedia, Malang, 2007, hlm. 302. 
bahan hukum yang erat hubungannya dengan bahan hukum primer dan dapat membantu menganalisis dan memahami bahan hukum primer, yang terdiri dari hasil penelitian, artikel, dan sebagainya yang terkait dengan pengetahuan tradisional.

2. Teknik Pengumpulan Bahan Hukum Data yang digunakan dalam penelitian ini diperoleh dari penelusuran melalui kegiatan studi kepustakaan, yaitu mengumpulkan berbagai bahan hukum baik yang berupa tulisan, dan sebagainya yang terkait dengan pengetahuan tradisional. Dokumen yang digunakan dapat berupa dokumen resmi maupun dari hasil penelitian yang memiliki kesesuaian data dengan penelitian yang dilakukan oleh peneliti. ${ }^{8}$

3. Teknik Analisis Bahan Hukum

Data penelitian ini dianalisis dengan menggunakan teknik analisis isi substansi hukum (legal content analysis) yang ditujukan untuk menganalisis rumusanrumusan dalam peraturan perundangundangan dan bahan hukum lainnya untuk menemukan kelemahan pengaturan pengetahuan tradisional dalam rancangan Undang-undang Pengetahuan Tradisional dan Ekspresi Budaya Tradisional.

\section{Pembahasan}

A. PerlindunganHukumPengetahuan Tradisional dan Ekspresi Budaya Tradisional dalam Rancangan Undang-undang Pengetahuan Tradisional dan Ekspresi Budaya Tradisional Ditinjau dari Aspek Pembagian Keuntungan yang Adil (benefits) berdasarkan Pasal 8j United Nations Convention on Biological Diversity

Sebelum menganalisis lebih dalam tentang Rancangan Undang-undang Pengetahuan Tradisional dan Ekspresi Budaya Tradisional berikut ini dipaparkan secara terpisah apa yang dimaksud dengan Pengetahuan Tradisional (PT) dan Ekspresi Budaya Tradisional (EBT). ${ }^{9}$

\section{Pengetahuan tradisional}

Istilah pengetahuan tradisional (diterjemahkan dari traditional knowledge) adalah istilah umum yang mencakup ekspresi kreatif, informasi dan know how yang secara khusus mempunyai ciri-ciri sendiri dan dapat mengidentifikasi unit sosial. ${ }^{10}$

Pengertian traditional knowledge dapat dilihat secara lengkap dalam Article 8 J Traditional Knowledge, Innovations, and Practices Introduction yang menyatakan: ${ }^{11}$

Traditional Knowledge refers to the knowledge, innovation and

8 S. Nasution, Metode Penelitian Naturalistik-Kualitatif, Tarsito, Bandung, 1996, hlm. 86.

9 Sedyawati dalam naskah akademik, www.bphn.go.id, diakses 15 Oktober 2013 pukul 15.00 WIB.

10 Budi Agus Riswandi dan M. Syamsudin, Op. cit., hlm. 26.

11 Ibid., hlm. 27. 
practices of indigenous and local communities around the world. Develop from experience gained over the centuries and adapted to the local culture and environment, traditional knowledge is transmitted orally from generation to generation. It tends to be collectively owned and takes the form of stories, songs, folklore, proverbs, cultural values, beliefs, rituals, community laws, local language, and agricultural practices, including the development of plant species and animal breeds. Traditional knowledge is mainly of a practical nature, particularly in such fields as agriculture, fisheris, health, horticulture, and forestry. (Pengetahuan tradisional merujuk pada pengetahuan, inovasi, dan praktik dari masyarakat asli dan lokal di seluruh dunia.Dikembangkan dari pengalaman melalui negaranegara dan diadaptasi ke budaya lokal dan lingkungan, pengetahuan tradisional ditransmisikan secara lisan dari generasi ke generasi.Hal itu menjadi kepemilikan secara kolektif dan mengambil bentuk cerita, lagu, foklore, peribahasa, nilai-nilai budaya, keyakinan, ritual hukum masyarakat, bahasa daerah dan praktik pertanian, mencakup pengembangan spesies tumbuhan dan keturunan binatang.Pengetahuan tradisional utamanya merupakan praktik alamiah, secara khusus seperti dalam wilayah pertanian, perikanan, kesehatan, hortikultural dan kehutanan).

The Director General of United Nations

Educational, Scientific and Cultural Organization mendefinikan trational knowledge yang menyatakan: ${ }^{12}$
The indigenous people of the world posses animmenseknowledgeof their environments, based on centuries of living close to nature. Living in and from the richness and variety of complex ecosystems, they have an understanding of the properties of plants and animals, the functioning of ecosystems and the techniques for using and managing them that is particular and often detailed. In rural communities in developing countries, locally occurring species are relied on for many - sometimes all-foods, medicines, fuel, building materials and other products. Equally, people is knowledge and perceptions of the environment, and their relationship with it, are often important elements of cultual identity. (Dunia orang-orang asli yang menguasai pengetahuan luas sekali dari lingkungan mereka yang berdasar pada kehidupan alamiah yang tertutup selama berabadabad.Kehidupan dalam dan dari ketidakpunyaan sampai pada suatu ekosistem kompleks yang beragam, mereka memahami kekayaan dari tumbuh-tumbuhan dan binatang, memfungsikan ekosistem dan teknik-teknik untuk menggunakan dan mengelola tumbuhan dan binatang tersebut secara khusus dan detail. Dalam masyarakat pedesaan di negara-negara berkembang, secara lokal menjadi spesies yang banyak - terkadang semuamakanan, obat-obatan, minyak, material pembangunan dan produkproduk lainnya. Sama-sama, orangorang yang merupakan lingkungan pengetahuan dan persepsi, dan hubungan mereka dengan itu adalah merupakan elemen penting dari identitas budaya) 
Sementara itu masyarakat asli sendiri memiliki pemahaman sendiri yang dimaksud traditional knowledge adalah: ${ }^{13}$

a. Traditional knowledge merupakan hasil pemikiran praktis yang didasarkan atas pengajaran dan pengalaman dari generasi ke generasi.

b. Traditional knowledge merupakan pengetahuan di daerah perkampungan.

c. Traditional knowledge tidak dapat dipisahkandarimasyarakatpemegangnya, meliputi kesehatan, spiritual, budaya, dan bahasa dari masyarakat pemegang. Hal ini merupakan way of life. Traditional knowledge lahir dari semangat untuk hidup (survive).

d. Traditional knowledge memberikan kredibilitas pada masyarakat pemegangnya.

Dari pemahaman ini, Traditional knowledge dapat diartikan sebagai pengetahuan tradisional yang dimiliki oleh masyakarakat daerah atau tradisi yang sifatnya turun-temurun.Pengetahuan tradisional itu sendiri ruang lingkupnya sangat luas, dapat meliputi bidang seni, tumbuhan, arsitektur, dan lain sebagainya.

Dengan adanya pluralitas golongan etnik yang luar biasa di Indonesia (sekitar 500 jumlahnya), maka dengan sendirinya dapat diharapkan terdapat variasi luar biasa dari Pengetahuan Tradisional dalam berbagai bidang kehidupan. Bidang-bidang yang dapat disebutkan adalah misalnya: kesenian, landasan pengetahuan dalam sistem kepercayaan, sistem penyembuhan, penyiapan makanan, praktek pertanian dalam arti luas, transportasi, arsitektur, serta pembuatan berbagai benda yang digunakan dalam kehidupan. Di dalam cakupan seluruh pengetahuan itu termasuk berbagai teknologi maupun berbagai nilai, kaidah, dan aturan sebagian pengetahuan tradisional masih berfungsi penuh di dalam suku bangsa atau komunitas pemilik aslinya. Faktor yang menyebabkan kondisi tersebut kemungkinan adalah: 1). Penggunaan Pengetahuan Tradisional tersebut masih dirasakan sebagai penanda jatidiri budaya yang dianggap dan dirasakan perlu dipertahankan; atau 2). Aspek tertentu dari Pengetahuan Tradisional itu dapat diintegrasikan ke dalam segi-segi kehidupan yang dipandu oleh nilai-nilai modern (keterbukaan, keilmiahan, keadilan demokratik). Contoh dari yang pertama, yaitu Pengetahuan Tradisional sebagai penanda jatidiri budaya diperlihatkan oleh penggunaannya dalam kaitan dengan busana, boga, kaida-kaida estetik, penggunaan bahasa, dan lain-lain. Adapun hal yang disebutkan terakhir itu dapat dicontohkan oleh penggunaan Pengetahuan Tradisional dalam industri farmasi, kosmetika, pertekstilan dan lain-lain, disamping juga pengkajian Pengetahuan Tradisional dalam rangka upaya pengembangan ilmu. Dengan kata lain, kegunaan Pengetahuan Tradisional (PT) dalam kehidupan di masa kini berada dalam 
dua ranah pengelolaan yaitu:

a. Pelestarian dalam arti pemertahanan eksistensinya, baik dalam keseluruhan format aslinya maupun dalam formatformat dan atau pengembangan baru, mengikuti gagasan-gagasan kreatif pemiliknya; atau

b. Pemanfaatan untuk dikembangkan dalam upaya ekonomi/industrial, di mana terkait hak-hak atas kekayaan intelektual dari kelompok/ komuniti/suku bangsa sebagai pemilik asal dari Pengetahuan Tradisional (PT) yang dimanfaatkan itu.

Adapun teknologi tradisi khususnya dapat dipilah ke dalam:

a. Teknik-teknik produksi barang (dalam berbagai bahan, misalnya logam, tekstil, kayu, keramik, rempah, dan lain-lain)

b. Teknik-teknik melakukan sesuatu, seperti : mengenakan busana, melaksanakan gerakan-gerakan dalam tarian, memainkan instrumen-instrumen musik, memasak, dan lain-lain; dan

c. Teknik-teknik penataan lingkungan (terkait dengan tata permukiman, pengendalian air, pengunaan hutan, dan lain-lain).

Upaya pemertahanan dan pengembangan teknik-teknik tersebut dapat diletakkan dalam posisi strategis, dengan fungsi sebagai berikut: ${ }^{14}$

1. Pengkayaan pengalaman "berpartisipasi dalam kebudayaan" (dan ini sesuai dengan Pasal 27 dari Universal
Declaration pf Human Right, yang berbunyi " Everyone has the right freely to participate in the cultural life of the community..."); kekayaan pengalaman itu dapat pula menumbuhkan rasa mandiri dan berkepribadian;

2. Faktor untuk dikembangkan dalam industri budaya sebagai keunggulan (sekurang-kurangnya) komparatif; bahkan dengan workmanship yang bermutu tinggi faktor teknik tradisional itu dapat pula menjadi suatu keunggulan kompetitif;

3. Penataan lingkungan disesuaikan dengan kebutuhan-kebutuhan yang berkembang

\section{Ekspresi budaya tradisional}

Ekspresi Budaya Tradisional (EBT), atau di dalam wacana di tingkat internasional seringkali digunakan istilah expressions of folklore, adalah segala sesuatu yang dianggap milik bersama suatu komunitas atau suatu masyarakat, dan penciptaannya anonim. Secara garis besar Ekspresi Budaya Tradisional (EBT), sebagaimana karya budaya pada umumnya, dapat digolongkan atas yang tangible (dapat disentuh, berupa benda padat) dan yang intangble (termasuk ke dalamnya nilai-nilai, konsep, dan juga tata tindakan seperti upacara, teater, tari, serta musik dan sastra). ${ }^{15}$ Ungkapan-ungkapan seni tradisional ini dapat mengandung di dalamnya :

1. Nilai-nilai estetik, dan ini pada gilirannya terkait dengan teknik-teknik berungkap 
(para pelakunya) maupun teknik-teknik dalam membuat peralatan pendukungnya (instrumen dan properti);

2. Nilai-nilai simbolik, yang dapat terkait dengan pandangan dunia serta sistem kepercayaan pada kebudayaan yang bersangkutan; dan Fungsi dalam peneguhan sistem kepercayaan dan atau sistem sosial dalam masyarakat pendukung kebudayaan yang bersangkutan. ${ }^{16}$

3. Pengetahuan tradisional dan ekspresi budaya tradisional di dalam rezim hak kekayaan intelektual. ${ }^{17}$

Alasan hukum pengetahuan tradisional dan ekspresi budaya tradisional harus diatur secara sui generis karena konsep pengetahuan tradisional sangat berbeda dengan konsep yang diatur dalam HKI.Dalam hal ini konsep dalam HKI adalah hak milik yang bersifat individual sedangkan konsep yang terdapat dalam pengetahuan tradisional adalah hak milik yang bersifat komunal. Walaupun dalam Pasal 10 ayat 1 dan 2 UUHC mengatur bahwa:

(1) Negara memegang Hak Cipta atas karya peninggalan prasejarah, sejarah, dan benda budaya nasional lainnya.

(2) Negara memegang Hak Cipta atas folklor dan hasil kebudayaan rakyat yang menjadi milik

bersama, seperti cerita, hikayat, dongeng, legenda, babad, lagu, kerajinan tangan, koreografi, tarian, kaligrafi, dan karya seni lainnya.

Artinya, bahwa negara yang menguasai pengetahuan tradisional dan ekpresi budaya tradisional, namun demikian sangat sulit untuk menerapkan pasal tersebut karena disamping ketidakjelasan pemerintah mana yang diberikan kewenangan penguasaan atas pengetahuan tradisional dan ekspresi budaya tradisonal juga tidak adanaya peraturan pelaksana yang mengatur lebih lanjut tentang pengetahuan tradsional dan ekspresi budaya tradisional.

Oleh karena itu ketika terjadi pengetahuan tradisional dan ekspresi budaya tradisional bangsa Indonesia dipakai untuk promosi wisata oleh Malaysia dengan menggunakan lagu rasa sayange dari Ambon dan Reog Ponorogo dari Ponorogo bahkan mendaku batik sebagai pengetahuan tradisional dari bangsa Malaysia hal ini sangat melukai harga diri bangsa Indonesia dan juga sangat merugikan dari aspek ekonomi (komersial). Kemudian dibuatlah Rancangan Undang-Undang tentang Perlindungan dan Pemanfaatan Kekayaan Intelektual Pengetahuan Tradisional dan Ekspresi Budaya Tradisioal (untuk penulisan selanjutnya disingkat RUU PTEBT) yang mengatur pengetahuan tradisonal tersendiri di luar sistem HKI. Pengaturan secara sui generis ini ke depan diharapkan dapat 
memberikan manfaat ekonomi yang lebih baik bagi masyarakat komunal (dalam RUU PTEBT menggunakan istilah kustodian $)^{18}$ sebagaimana terdapat dalam menimbang RUU PTEBT huruf d bahwa keanekaragaman etnik atau suku bangsa dengan karya intelektualnya merupakan warisan budaya yang bernilai tinggi, dalam kenyataannya telah menjadi daya tarik untuk dimanfaatakan secara komersial sehingga pemanfaatan tersebut perlu diatur untuk kemaslahatan masyarakat.

Lebih lanjut Pasal 1 angka 4 RUU PTEBT mengatur bahwa Perlindungan adalah segala bentuk upaya melindungi Pengetahuan Tradisional dan/ atau Ekspresi Budaya Tradisional terhadap pemanfaatan secara komersial yang dilakukan tanpa izin. Kemudian dalam pasal 1 angka 6 RUU PTEBT mengatur bahwa pemanfaatan adalah pendayagunaan Pengetahuan Tradisional dan/ atau Ekspresi Budaya tradisional secara komersial. Dengan demikian tujuan dari RUU PTEBT ini lebih pada tujuan komersial untuk kustodian dan berkesesuaian dengan aspek pembagian keuntungan yang adil (benefits) berdasarkan Pasal 8j United Nations Convention on Biological Diversity.

Dalam hal ini untuk pemanfataan pengetahuan tradisonal dan ekspresi budaya tradisional (untuk penulisan selanjutnya disingkat PTEBT) secara komersial maka ruang lingkup PTEBT dalam RUU PTEBT lebih jelas dibandingkan pengaturan dalam sistem HKI baik yang tertuang dalam UU Hak Cipta maupun UU Paten. Hal ini sebagaimana diatur dalam Pasal 2 RUU PTEBT:

(1) Perlindungan Pengetahuan Tradisional dan Ekspresi Budaya Tradisional mencakup unsur budaya yang:

a. Disusun, dikembangkan, dipelihara, dan diturunkan sebagai tradisi; dan

b. Memiliki karakteristik khusus sebagai identitas budaya masyarakat tertentu yang melestarikannya;

(2) Pengetahuan Tradisional yang dilindungi sebagaimana dimaksud pada ayat 1 mencakup ide/ gagasan, konsep, keterampilan, pembelajaran dan praktik kebiasaan lainnya, dan inovasi yang membentuk gaya hidup masyarakat tradisional termasuk di antaranya pengetahuan pengobatan termasuk obat terkait dan tata cara penyembuhan, pengetahuan tentang ruang dan waktu, pengetahuan pertanian, pengetahuan lingkungan alam, pengetahuan tentang flora dan fauna, pengetahuan tetnang zat dan bahan mentah, pengetahuan tentang anatomi tubuh, pengetahuan tentang astronomi, serta pengetahuan yang terkait dengan sumber daya genetik.

(3) Ekspresi Budaya Tradisional yang dilindungi sebagaimana dimaksud pada ayat 1 mencakup salah satu atau kombinasi bentuk ekspresi antara lain;

18 Kustodian PTEBT adalah komunitas masyarakat lokal atau masyarakat adat yang memelihara dan mengembangkan Pengetahuan Tradisional dan ekspresi budaya Tradisional tersebut secara tradisional dan komunal. 
a. Karya sastra ataupun narasi informatif dalam bentuk lisan maupun tulisan yang berbentuk prosa maupun puisi, dalam berbagai tema dan kandungan isi pesan

b. Seni musik, mencakup antara lain: vokal, instrumental atau kombinasinya;

c. Seni gerak, mencakup antara lain: tarian, beladiri, dan permainan;

d. Seni teater, mencakup antara lain: pertunjukna wayang dan sandiwara rakyat;

e. Seni tempa, mencakup antara lain: pembuatan senjata tradisional, alat musik tradisional, perhiasan, alat produksi, dan peralatan rumah tangga;

f. Seni rupa, baik dalam bentuk dua dimensi maupun tiga dimensi yang terbuat dari berbagai macam bahan serti kulit, kayu, bambu, loga, batu, keramik, kertas, tekstil, dan lain-lain atau kombinasinya; dan

g. Upacara adat, mencakup antara lain: prosesi, perlengkapan, pembuatan alat dan bahan perlengkapan, serta penyajiannya.

Ditinjau dari pembagian hasil pemanfaatan maka RUU PTEBT lebih jelas dalam mengatur dibandingkan dengan pengaturan dalam sistem HKI baik dalam UU Hak Cipta maupun UU Paten, hal ini diatur dalam Pasal 15 RUU PTEBT:

(1) Pihak yang melakukan pemanfaatan wajib melakukan pemanfaatan kepada
Kustodian Pengetahuan Tradisional dan Ekspresi Budaya Tradisional sesuai dengan kesepakatan yang dituangkan di dalam perjanjian pemanfaatan.

(2) Pembagian hasil pemanfaatan sebagaimana dimaksud pada ayat (10 ditentukan berdasarkan kesepakatan dengan memperhatikan kepatutan dan kewajaran.

Kemudian dalam Pasal 16 RUU PTEBT

Pihak yang Melakukan Pemanfaatan:

(1) Kustodian Pengetahuan Tradisional dan Ekspresi Budaya Tradisional berhak menerima pembagian hasil pemanfaatan dari Pemegang Izin Akses Pemanfaatan sesuai dengan kesepekatan yang dituangkan di dalam perjanjian pemanfaatan.

(2) Kustodian sebagaimana dimaksud pada ayat (1) wajib memanfaatkan pembagian hasil pemanfaatan guna pelestarian dan pengembangan Pengetahuan tradisional dan Ekspresi Budaya Tradisional.

Dengan demikian RUU PTEBT lebih baik dan sempurna dalam hal mengatur pemanfaatan pengetahuan tradisional secara komersial guna kepentiangan masyarakat lokal (kustodian) dan hal ini berkesesuaian dengan aspek pembagian keuntungan yang adil (benefits) berdasarkan Pasal 8j United Nations Convention on Biological Diversity. Namun demikian, terkait dengan RUU PTEBT maka kedepan sangat penting arti dari inventarisasi dan dokumentasi. Sampai saat ini, upaya dokumentasi PTEBT yang sudah 
terlihat dilakukan oleh pemerintah hanyalah pada PTEBT Indonesia yang sudah mendunia seperti wayang, keris, batik. Untuk PTEBT lainnya, upaya pemerintah hanya sampai pada proses inventarisasi saja. Belum ada kejelasan prosedur dan kerja-sama di antara kementerian di Indonesia untuk mengorganisasi proses dokumentasi dan database PTEBT. Saat ini, Kementerian Kebudayaan dan Pariwisata dan Kementerian Hukum dan HAM, Dirjen HKI, melakukan proses inventarisasi PTEBT secara sendiri-sendiri. RUU PTEBT bahkan tidak mengklarifkasi kementerian mana yang akan ditugaskan untuk melaksanakan proses dokumentasi dan database atas PTEBT Indonesia.

Pasal 1 angka 17 RUU PTEBT hanya mendefiniskan Menteri adalah "Menteri yangmenanganiurusan pemerintahan dibidang Perlindungan dan PemanfaatanKekayaan Intelektual Pengetahuan Tradisional dan Ekspresi Budaya Tradisional".Seharusnya RUU PTEBT sudah mengatur dengan jelas institusi atau kementerianmana yang ditugaskan untuk melakukan dokumentasi dan menyusun database atasPTEBT Indonesia. Pengaturan yang jelas sejak awal akan dapat mempersiapkaninstitusi atau kementerian yang bersangkutan untuk melaksanakan tugaspendokumentasian dan penyusunan database PTEBT, sehingga dapat menghindariterjadinya lubang hukum sewaktu RUU PTEBT diundangkan dan dilaksanakan. ${ }^{19}$ Dengan demikian melalui RUU PTEBT maka ke depan perlindungan hukum pengetahuan tradisional dan ekspresi budaya tradisional dapat terwujud lebih baik.

\section{Simpulan}

Perlindungan terhadap pengetahuan tradisional menjadi isu yang harus diperhatikan oleh negara-negara berkembang. Hal ini disebabkan, negara berkembang yang kaya akan pengetahuan tradisional seringkali menjadi korban dari pihak-pihak yang tidak bertanggungjawab yang ingin mengambil keuntungan atas pengetahuan tradisional masyarakat lokal. RUU PTEBT lebih tegas dan jelas dalam mengatur PTEBT, dalam hal ini meliputi tujuan perlindungan PTEBT guna kepentingan komersial, termasuk di dalamnya adalah ruang lingkup perlindungan PTEBT dan Pembagian hasil pemanfaatan. Hal ini telah sesuai dengan aspek pembagian keuntungan yang adil (benefits) berdasarkan Pasal 8j United Nations Convention on Biological Diversity. 


\section{DAFTAR PUSTAKA}

\section{Buku}

Adrian Sutedi, 2009, Hak Atas Kekayaan

Intelektual, Sinar Grafika, Jakarta.

Bambang Sunggono, 2002, Metodologi

Penelitian Hukum, Edisi I, Raja

Grafindo Persada, Jakarta.

Bambang Waluyo, 2002, Penelitian Hukum

dalam Praktek, Cetakan ke-3, Sinar

Grafika, Jakarta.

Budi Agus Riswandi dan M. Syamsudin,

2005, Hak Kekayan Intelektual

dan Budaya Hukum, RajaGrafindo

Persada, Jakarta.

Burhan Ashshofa, 2001, Edisi 3, Metode

Penelitian Hukum, Rineka Cipta, Jakarta.

Jonny Ibrahim, 2007, Teori dan Metodologi

Penelitian Normatif, Bayumedia,

Malang.

Satjipto Rahardjo, 2000, Ilmu Hukum, Edisi

Revisi, Citra Aditya Bakti, Bandung.

S. Nasution, 1996, Metode Penelitian

Naturalistik-Kualitatif， Tarsito,

Bandung.

Tim Lindsey et. al., 2003, Hak Kekayaan

Intelektual suatu Pengantar, Alumni.

Bandung.
Jurnal

Afifah Kusumadara, Pemeliharaan dan Pelestarian Pengetahuan Tradisional dan Ekspresi Budaya Tradisional Indonesia: Perlindungan Hak Kekayaan Intelektual dan Non-Hak Kekayaan Intelektual, Jurnal Hukum, Volume 18 No. 1, Januari 2011.

Jurnal Bisnis, Manajemen dan Ekonomi, Volume 7, No. 3, Februari 2006.

\section{Peraturan Perundang-undangan}

UU No. 19 Tahun 2002 tentang Hak Cipta.

UU No. 5 Tahun 1994 tentang Ratifikasi

Konvensi Keanekaragaman Hayati.

Agreement on Trade Related Aspects on Intellectual property Rights (TRIPs).

United Nations Convention on Biological Diversity.

Rancangan Undang-undang Pengetahuan Tradisional dan Ekspresi Budaya Tradisional.

\section{Naskah Internet}

Naskah Akademik Rancangan Undangundang Pengetahuan Tradisional dan Ekspresi Budaya Tradisional, www. bphn.go.id.

Perlindungan Hak atas Kekayaan Intelektual terhadap Pengetahuan Tradisional, www.alsaindonesia.org. 